\title{
First records of the invasive box tree moth Cydalima perspectalis (Walker, 1859) (Lepidoptera: Crambidae) in south-eastern Poland
}

\author{
Jarosław BURY ${ }^{1}$, Tomasz OLBRYCHT ${ }^{2}$, Krzysztof MAZUR ${ }^{3}$, \\ Paweł BABUla ${ }^{4}$ and Paweł CzUDEC ${ }^{5}$ \\ ${ }^{1}$ Markowa 1498, 37-120 Markowa, Poland; e-mail: jarekbury2@wp.pl (corresponding author) \\ ${ }^{2}$ University of Rzeszów, Faculty of Biology and Agriculture, Department of Agroecology, \\ M. Cwiklińskiej 1a, 35-601 Rzeszów, Poland; e-mail: tkolbr@ur.edu.pl \\ ${ }^{3}$ Umieszcz 76, 38-204 Umieszcz, Poland \\ ${ }^{4}$ Królewska 21, 35-616 Rzeszów, Poland \\ ${ }^{5}$ Malczewskiego 3/44, 35-114 Rzeszów, Poland
}

\begin{abstract}
The paper presents the first records of box tree moth from a few localities situated in 5 UTM squares in the Podkarpacie region - in the south-eastern Poland. This species, native to the subtropical regions of East Asia, was accidentally introduced into Europe in the first decade of the 21st century. Box tree moth was observed for the first time in Poland in 2012, and more recently in the Podkarpacie region in 2016. The rapid expansion of the species is mostly explained by the transfer of its preimaginal stages along with its main host plant (Buxus spp.).
\end{abstract}

Key words: invasive species, new records, faunistic data, SE Poland. Podkarpacie

\section{INTRODUCTION}

Cydalima perspectalis (Walker, 1859) is a member of the Crambidae family, and the subfamily of Spilomelinae. Its native range covers the subtropical regions of south-east Asia, from India across China, Taiwan, Korea and Japan to the Russian Far East (Mally \& Nuss 2010). In Europe the box tree moth was first detected in the first decade of the 21st century. The species was recorded from Germany as new to the fauna of Europe after its accidental introduction, probably in the period 2005-2007 (Billen 2007, Krüger 2008). Preimaginal stages of the species can be easily spread from China with various decorative varietes of its main host plant (Buxus spp.).

At present C. perspectalis is known from many European countries - Germany, Switzerland (Käppeli 2008, Sigg 2009), Liechtenstein (Slamka 2010), Luxemburg (Ries et al. 2017), The Netherlands (Muus et al. 2009), Belgium (Casteels et al. 2011), Denmark (Hobern 2013), Great Britain (Mitchell 2009), France (Feldtrauer et al. 2009), Spain (Pérez-Otero 2014, Pino Pérez \& Pino Pérez 2014), Austria (Rodeland 2009, Kuzmits 2012), Italy (Griffo et al. 2012, Bella 2013), Czech Republic (Šumpich 2011), Slovakia (Pastorális et al. 2013), Hungary (Sáfián \& Horváth 2011), Romania (Székely et al. 2011), Slovenia (Seljak 2012), Croatia (Koren \& Črne 2012, Matošević 2013), Serbia (Konjević et al. 2015, Stojanović et al. 2015), Montenegro (Hrnčić \& Radonjić 2014), Bosnia and Herzegovina (Ostojić et al. 2014), Albania (Raineri et al. 2017), Bulgaria (Beshkov et al. 2015), Greece (Strachinis et al. 2015), Turkey (Hizal et al. 2012), Georgia (Matsiakh 2014), Ukraine (Budashkin 2016) and Russia (Proklov \& Karayeva 2013). The chronology of the spread of $C$. perspectalis in some European countries (omitting data from Poland and Ukraine) is given by Raineri et al. (2017) who reported on the threat of xerothermophilous formations with Buxus sempervirens, the nature 2000 habitat in Liguria with this pest. 
In Poland, the species was observed for first time in 2012 in the Dolny Ślask region, and subsequently in the Opolszczyzna and Małopolska regions in 2015 (Blaik et al. 2016).

The biology of $C$. perspectalis is very well known in its native Asia (Wan et al. 2014). The species produces three to five generations per year, and caterpillars feed on the leaves of its main host plants (Buxus spp.). Other plants such Euonymus japonicus and Ilex purpurea are also mentioned as host plants of the species in Japan (Mally \& Nuss 2010). In southern European conditions C. perspectalis produces three to four, and in central European conditions two to three, generations per year. Larvae feed so far only on box tree species which in Europe are mostly the ornamental plants and hedges. Tests with other plants: Euonymus japonicas, Ilex aquifolium and Ligustrum vulgare, have shown that $C$. perspectalis caterpillars are not able to feed on them (Matošević et al. 2017). The species overwinters as a juvenile larva (about 5-10 $\mathrm{mm}$ long), protected in a hibernarium made of two living host plant leaves solidly joined by silk. The 2-6 week period of winter diapause is obligatory. In Europe, in the regions where the species has been introduced, it has no natural enemies, and the damage caused by caterpillars can be very serious.

At present, in all of the colonized countries, C. perspectalis is treated as a pest with great economic importance.

The aim of this paper is to note the present of Cydalima perspectalis in the most eastern region of the south Poland - the Subcarpathian Province (Podkarpacie).

\section{MATERIALS AND METHODS}

The fieldwork was carried out in the Podkarpacie region in south-eastern Poland, over the period 2016-2017. The names of mesoregions and macroregions are given according to Kondracki (2002). UTM (Universal Transverse of Mercator) co-ordinates (10x10 km grid) are provided for each site of observation. The caterpillars were sought on the main host plant Buxus spp. in city parks and village gardens. The moths were attracted to the UV light. The light traps were installed in 15 sites (Fig. 1) in various urban, suburban and rural habitats, in the same places during both years of observation. Only one trap was installed on each site. The trapping season covered the period from early March to late November, and each trap was controlled at least once a week. Some individuals were caught and deposited in the private collections of the authors. The occurrence of the rest was documented by photographs.

\section{RESULTS}

Imagines of C. perspectalis in the period 2016-2017 were found in the Podkarpacie region at the following sites:

2016

- Pogórze Środkowobeskidzkie (Beskidy Środkowe Foothills)

- Pogórze Strzyżowskie (Strzyżów Foothills): EA24 Grabiny, 17 Sep 2016, 1 ex., idem, 18 Sep 2016, 3 exx., ad lucem, leg. et coll. Ł. Solecki.

- Pogórze Jasielskie (Jasło Foothills): EA30 Umieszcz, 26 Sep 2016, 1 ex., ad lucem, leg. et coll. K. Mazur.

- Pogórze Dynowskie (Dynów Foothills): EA73 Rzeszów-Zalesie, 02 Oct 2016, 1 ex., ad lucem, leg. et coll. T. Olbrycht.

2017

- Pogórze Środkowobeskidzkie (Beskidy Środkowe Foothills)

- Pogórze Strzyżowskie (Strzyżów Foothills): EA24 Grabiny, 12-15 Aug 2017, 4 caterpillars on Buxus sp., home garden, obs. Ł. Solecki. 
- Pogórze Dynowskie (Dynów Foothills): EA73 Rzeszów-Zalesie, historical park, 22 Jun 2017, 2 exx., idem, 18 Aug 2017, 19 exx., idem, 19 Aug 2017, 12 exx., idem, 03 Sep 2017, 18 exx., idem, 09 Sep 2017, 4 exx., ad lucem, leg. et coll. T. Olbrycht. EA74 Rzeszów-Mieszka I, Letnia str., Aug 2017, 1 ex., ad lucem, leg. et coll. Z. W. Czerniakowski, Rzeszów, 04 Sep 2017, 1 ex., ad lucem, obs. D. Wyczarski, RzeszówWilkowyja, 8 Aug 2017, 10 exx., around 1.30 after midnight to UV ligth, leg. et coll. P. Babula, Rzeszów-Osiedle Kmity, 10 Sep 2017, 5 exx., ad lucem, at the entrances to residential buildings, obs. \& photo. P. Czudec.

- Kotlina Sandomierska (Sandomierz Valley)

- Podgórze Rzeszowskie (Rzeszów Foreland): EA64 Zgłobień, 13 Sep 2017, 2exx., ad lucem, obs. \& photo. P. Czudec.

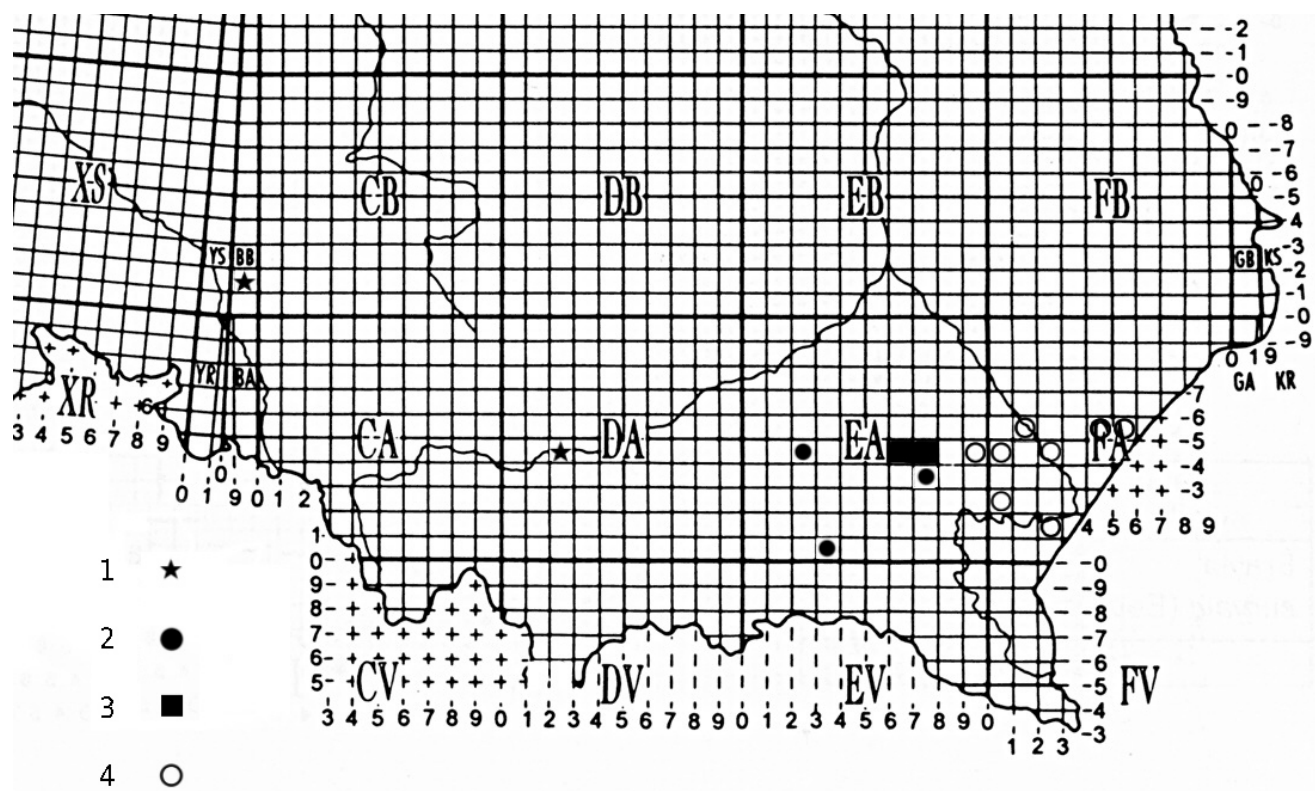

Fig. 1. Distribution of Cydalima perspectalis (Walker, 1859) in S \& SE Poland. 1- data from literature, 2 - new data from 2016, 3 - new data from 2017, 4 - localities where appearance of the species was not stated.

In the period 2016-2017 mature individuals appear in two well-separated broods - the first one in June and the second from the first decade of August to the first decade of October. The second brood was much more numerous than the first (Fig. 2).

Caterpillars have been observed in the surveyed area only on Buxus sp., despite a purposeful search for preimaginal stage individuals in many places.

\section{DISCUSSION}

Cydalima perspectalis was found in Podkarpacie, the most eastern region of the south Poland, for the first time in September 2016. The species had spread quickly in Poland, since it was first observed in the southwestern part of the country (Lower Silesia) in 2012. In 2015 the box tree moth was found in the two regions located further to the east (Opolskie and Małopolskie Voivodeships) of southern Poland (Blaik et al. 2016). At present the species is 
known in almost all southern regions of the country. The species has already been found in all southern neighbors: Hungary and the Czech Republic in 2010, Slovakia in 2012 and even in Ukraine (around Kiev, Transcarpathia and Crimea, although until 2015 it was not widespread outside these places) (Sáfián \& Horváth 2011, Šumpich 2011, Pastorális et al. 2013, Budashkin 2016, Oberemok et al. 2016, Nagy et al. 2017).



Fig. 2. Phenology of Cydalima perspectalis (Walker, 1859) in Podkarpacie region (SE Poland) in the period 2016-2017.

In the Podkarpacie region the box tree moth has colonized four mesoregions so far: the Jasło Foothills, Strzyżów Foothills, Dynów Foothills and Rzeszów Foreland, within two macroregions: the Beskidy Środkowe Foothills and Sandomierz Valley. Most of the observations come from urban areas, especially from the vicinity of Rzeszów, and only a few from the rural areas outside the city. The fact that in the year 2016 only 3 mature individuals were observed, while in 2017 there were already 77, suggests the high dynamism of the expansion process in the region. However, in almost half of the places studied, the species was not stated (Fig.1).

Thanks to the significant number of moth observations, the phenology of the species in the Podkarpacie region was initially established (Fig. 2). The phenology of the appearance of imagines observed in south-eastern Poland corresponds to observations from the western part of the country (Blaik et al. 2016). In the more southern countries, like Hungary, Slovakia and West Ukraine the species appears in three generations (Nagy et al. 2017). Finding caterpillars only on box tree confirms previous observations on the nutrition preferences of preimaginal stages of the species obtained in the other parts of Europe (Leuthardt \& Baur 2013, Matošević et al. 2017).

It should be noted that after the alien species as: Phyllonorycter issikii (Kumata 1963), Ph. robiniella (Clemens, 1859), Ph. platani (Staudinger, 1870) and Leptoglossus occidentalis Heidemann, $1910-C$. perspectalis is yet another invasive species of insect that has appeared in south-eastern Poland in recent years and potentially poses a serious threat to ornamental plants grown in parks and gardens (Czerniakowski \& Olbrycht 2015). Monitoring of the spread of these species would be desirable due to their economic importance (Nacambo et al. 2014). It is essential to do it not only on a regional scale, but also on national and international scale.

\section{REFERENCES}

BELLA S. 2013. The box tree moth Cydalima perspectalis (Walker, 1859) continues to spread in southern Europe: new records for Italy (Lepidoptera: Pyraloidea: Crambidae). Redia 46: 51-55.

BESHKOV S., ABADJIEV S. \& DIMITROV D. 2015. Cydalima perspectalis (Walker, 1859) (Lepidoptera: Pyraloidea: Crambidae: Spilomelinae). New invasive pest moth in Bulgaria. Entomologist’s Record and Journal of Variation 127: $18-23$. 
BILLEN W. 2007. Diaphania perspectalis (Lepidoptera: Pyralidae) - a new moth for Europe. Mitteilungen der Entomologischen Gesellschaft Basel 57: 135-137.

BlaIK T., HeBDA G. \& MASŁOWSKI J. 2016. Cydalima perspectalis (WALKER, 1859) - inwazyjny gatunek motyla w faunie Polski (Lepidoptera: Crambidae). Przyroda Sudetów 19: 121-124.

BUDASHKIN YU.I. 2016. Box wood moth - Cydalima perspectalis (Lepidoptera, Pyraustidae) - a new for the fauna of Ukraine and Crimea species of a dangerous pest of forestry and greenery. Ekosystemy. 5 (35): 36-39. [In Russian with English Abstract]

CASTEELS H., WitTERS J., VANDIERENDONCK S. \& VAN REMOORTERE L. 2011. First report of Cydalima perspectalis (Lepidoptera: Crambidae) in Belgium. 63rd International Symposium on Crop Protection (poster presentation).

CZERNiAKOWSKi Z.W. \& OlBRYCHT T. 2015. Invasive species and their role in historic park sites. Technical Transactions Architecture, Kraków, 5-A: 33-40.

Feldtrauer J.-F., Feldtrauer J.-J. \& Brua C. 2009. Premiers signalements en France de la Pyrale du Buis Diaphania perspectalis (Walker, 1859), espèce exotique envahissante s'attaquant aux Buis (Lepidoptera, Crambidae). Bulletin de la Societe Entomologique de Mulhouse 65: 55-58.

GRIFFO R., CESARONI C. \& DESANTIS M. 2012. Organismi nocivi introdotti in Italia nell'ultimo trienni. Informatore Agrario 68: 61-63.

HIzAL E., Kose M., YesiL C. \& KAYNAR D. 2012. The new pest Cydalima perspectalis (Walker, 1859) (Lepidoptera: Crambidae) in Turkey. Journal of Animal and Veterinary Advances, 11 (3): 400-403; DOI: 10.1653/024.095.0216.

HOBERN D. 2013. Cydalima perspectalis (WALKER, 1859). Available at http://www.flickr.com/photos/dhobem/9418970083/ (04 Nov 2017).

HRNČIĆ S. \& RADONJIĆ S. 2014. Cydalima perspectalis Walker (Lepidoptera: Crambidae) - nova invazivna štetočina šimšira u Crnoj Gori; 11. Simpozij o zaštiti bilja u Bosni i Hercegovini, Teslić, 04-06.11.2014. Zbornik rezimea 24-25.

KÄPPELI F. 2008. Der Buchsbaumzünsler - Im Eiltempo durch Basler Gärten. g’plus - die Gärtner-Fachzeitschrift (Zürich) 20: 33.

KONDRACKI J. 2002. Geografia regionalna Polski. Państwowe Wydawnictwo Naukowe, Warszawa. 444 pp.

KonJeViĆ A., MARKOVIĆ M. \& KEREŠI T. 2015. Nalazi šimširovog moljca Cydalima perspectalis (Walker, 1859) (Lepidoptera, Crambidae) u Vojvodini. Biljni lekar 43 (4): 387-395.

KoREN T. \& ČRnE M. 2012. The first record of the box tree moth, Cydalima perspectalis (Walker, 1859) (Lepidoptera, Crambidae) in Croatia. Natura Croatica 21: 507-510.

KRÜGER E. O. 2008. Glyphodes perspectalis (WALKER, 1859) - neu für die Fauna Europas (Lepidoptera: Crambidae). Entomologische Zeitschrift 118: 81-83.

KuZMITS L. 2012. Cydalima perspectalis (WALKER, 1859) - bisher bekannte Vorkommen in Österreich und Zuchtergebnisse (Lepidoptera, Pyralidae). Joannea Zoologie 12: 99-103.

LEUTHARDT F. L. G. \& BAUR B. 2013. Oviposition preference and larval development of the invasive moth Cydalima perspectalis on five European box-tree varieties. Journal of Applied Entomology, 137: 437-444. DOI: 10.1111/jen.12013

MALLY R. \& NUSS M. 2010. Phylogeny and nomenclature of the box tree moth, Cydalima perspectalis (Walker, 1859) comb. n., which was recently introduced into Europe (Lepidoptera: Pyraloidea: Crambidae: Spilomelinae). European Journal of Entomology 107: 393-400; DOI: 10.14411/eje.2010.048.

MATOŠEVIĆ D. 2013. Box Tree Moth (Cydalima perspectalis, Lepidoptera; Crambidae), new invasive insect pest in Croatia. South-East European Forestry 4 (23): 89-94; DOI: 10.15177/seefor.13-09

MATOŠEviĆ D., LuKić I., BRAS A., LACKOVIĆ N. \& PERNEK M. 2017. Spatial distribution, genetic diversity and food choice of box tree moth (Cydalima perspectalis) in Croatia. South-East European Forestry 8 (1): 41-46; https://doi.org/10.15177/seefor.17-06.

MAтsiaKh I. 2014. Assessment of Forest Pests and Diseases in Protected Areas of Georgia. Final Report. Tbilisi. Available at www.enpi-fleg.org

MitCHELl A. 2009. Box tree moth Diaphania perspectalis (Walk.) - a new pyralid moth to Britain and Ireland. Atropos 36: 17-18.

MuUs T. S. T., VAN HAAfTEN E.-J. \& VAN DeVenter L. J. 2009: De buxusmot Palpita perspectalis (Walker) in Nederland (Lepidoptera: Crambidae). Entomologische Berichten 69: 66-67.

NACAmBo S., LeUthaRdT F. L. G., WAN H., Li H., HAYE T. \& BAUR B. 2014. Development characteristics of the box-tree moth Cydalima perspectalis and its potential distribution in Europe. Journal of Applied Entomology 138: 14-26; DOI: 10.1111/jen.12078

NAGY A., SZARUKan I., CSABAi J., Molnar A., Molnar B.P., KARPATI Z., SZANYi S. \& TóTH M. 2017: Distribution of the box tree moth (Cydalima perspectalis Walker, 1859) in the north-eastern part of the Carpathian Basin with a new Ukrainian record and Hungarian data. Bulletin OEPP/EPPO, 47(2): 279-282. DOI: 10.1111/epp.12384

OBEREMOK V.V., LAIKOVA K.V., SHUMSKYKH M.N. \& ZAITSEV A.S. 2016. The first record of box tree moth in Crimea and a novel perspective of its biological control based on Lymantria dispar multicapsid nuclear polyhedrosis virus and DNA insecticides approach. Entomologia Generalis 36 (3): 207-217; DOI: 10.1127/entomologia/2017/0333

Ostojić I., Zovko M., Petrović D. \& Elez, D. 2015. New records of box tree moth Cydalima perspectalis (Walker, 1859 ) in Bosnia and Herzegovina. Works of the Faculty of Agriculture University of Sarajevo 60: 139-143. 
PAstorális G., Elsner G., KOPEÈEK F., Kosorin F., LAŠtŮVKA A., Lendela A., LiŠKA J., NiMY J., RichteR I., STEFANOVIE R., ŠUMPICH J. \& TOKAR Z. 2013. Fourteen Lepidoptera species new to the fauna of Slovakia. Folia Faunistica Slovaca 18: 1-12.

PÉREZ-OTERo R., MANSILLA J. P. \& VidAL M. 2014. Cydalima perspectalis Walker, 1859 (Lepidoptera, Crambidae): a new threat for Buxus spp. in thelberian Peninsula. Arquivos Entomolóxicos, 10: 225-22 [In Spanish with English abstract]

Pino PÉRez J. J. \& Pino PÉRez R. 2014. Segunda cita de Cydalima perspectalis (Walker, 1859) (Lepidoptera, Crambidae) para Galicia (NO España). Boletin BIGA, 14: 47-50.

Proklov V.V. \& Karayeva S. Z. 2013. New and interesting Lepidoptera records from Chechen Republic (Russia). Caucasian Entomological Bulletin 9: 281-282.

RAineri V., BONeChi F., CARACCIOlO D., CResta P. \& MARIOTTI M. 2017. Cydalima perspectalis (Walker, 1859) (Lepidoptera, Crambidae) and the threats for the Nature 2000 habitat 5110 in Liguria (NW Italy). Bollettino dei Musei e Degli Istituti Biologici dell'Università di Genova 79: 215-236.

Ries C., Arendt A., Braunert C., Christian S., Dohet A., Frantz A., Geimer G., Hellers M., Massard J. A., Mestdagh X., Proess R., Schneider N. \& Pfeiffenschneider M. 2017. Environmental impact assessment and black, watch and alert list classification after the ISEIA Protocol of invertebrates in Luxembourg. Bulletin de la Société des naturalistes luxembourgeois, 119: 63-70.

RoDELAND J. (ed.). 2009. Lepiforum. Available at http://lepiforum.de/ (04 Nov 2017).

SÁfiÁn S. \& HoRVÁth B. 2011. Box Tree Moth - Cydalima perspectalis (WALKER, 1859), New member in the Lepidoptera fauna of Hungary (Lepidoptera: Crambidae). Natura Somogyiensis 19: 245-246.

SELJAK G. 2012. Six new alien phytophagous insect species recorded in Slovenia in 2011. Acta Entomologica Slovenica 20: 31-44.

SIGG C.-R. 2009. Auch das noch: Ein neuer Buchs-Schädling schlägt zu. Massive Schäden durch den Buchsbaumzünsler. Der Gartenbau (Solothurn) 4: 2-4.

Slamka F. 2010. Pyraloidea (Lepidoptera) of Central Europe. František Slamka Publishing, Bratislava, 176 pp.

Strachinis I., KaZilas C., Karamaouna F., PAPANiKOlaOU N.E., PARTSinevelos G.K. \& Milonas P.G. 2015 First record of Cydalima perspectalis (Walker, 1859) (Lepidoptera: Crambidae) in Greece. Hellenic Plant Protection Journal 8: 66-72; DOI: 10.1515/hppj-2015-0010

SzÉKELY L., DinCA V. \& MiHAi C. 2011. Cydalima perspectalis (Walker, 1859), a new species for the Romanian fauna (Lepidoptera: Crambidae: Spilomelinae). Buletin de Informare Entomologica 22 (3-4): 73-77.

ŠUMPICH J. 2011. Die Schmetterlinge der Nationalparke Podyjí und Thayatal. Die Schmetterlinge der Nationalparke Podyjí und Thayatal. Správa Národního parku Podyjí, Znojmo, 428 pp [In Czech and German, with English abstract]

Stojanović D.V., Konjević A., Marković M. \& Kereši T. 2015. Appearance of the box tree moth Cydalima perspectalis (Walker, 1859) (Lepidoptera, Crambidae) in Vojvodina (Lepidoptera, Crambidae) in Vojvodina. Biljni lekar 43 (4): 387-395.

Wan H, Haye T, Kenis M, NACAmbo S, Xu H, Zhang F \& Li H. 2014 Biology and natural enemies of Cydalima perspectalis in Asia: Is there biological control potential in Europe? Journal of Applied Entomology 138 (10): 715-722. DOI: https://doi.org/10.1111/jen.12132

\section{STRESZCZENIE}

\section{[Pierwsze obserwacje inwazyjnego gatunku motyla Cydalima perspectalis (Walker, 1859) (Lepidoptera: Crambidae) w południowo-wschodniej Polsce]}

Cydalima perspectalis (Walker, 1859) jest przedstawicielem rodziny Crambidae i podrodziny Spilomelinae. W naturze motyl ten zasiedla subtropikalne regiony południowowschodniej Azji, w Europie po raz pierwszy został stwierdzony w Niemczech w pierwszej dekadzie 21. wieku. W chwili obecnej znany jest $\mathrm{z}$ większości środkowo- i południowo europejskich krajów. W Polsce gatunek został stwierdzony po raz pierwszy w 2012 roku na zachodzie i szybko rozprzestrzenił się w południowej części kraju. W trakcie obserwacji dokonanych w latach 2016-2017 C. perspectalis został po raz pierwszy odnaleziony na Podkarpaciu (południowo-wschodnia Polska). Obecnie znany jest w czterech mezoregionach w centralnej i południowej części województwa (okolice Rzeszowa, Strzyżowa i Jasła). Ze względu na możliwość wyrządzania poważnych szkód w uprawach bukszpanu (Buxus spp.) motyl uznawany jest za groźnego szkodnika, o dużym znaczeniu gospodarczym. Jest to kolejny inwazyjny gatunek owada zanotowany w ostatnich latach na Podkarpaciu. 